\title{
Depth distribution of nearshore temperate fish larval assemblages near rocky substrates
}

\author{
RICARDO BELDADE, RITA BORGES AND EMANUEL J. GONÇALVES* \\ ECO-ETHOLOGY RESEARCH UNIT, INSTITUTO SUPERIOR DE PSICOLOGIA APLICADA, R. JARDIM DO TABACO 34, II49-O4I LISBOA, PORTUGAL \\ *CORRESPONDING AUTHOR: emanuel@ispa.pt
}

Received March 30, 2006; accepted in principle June 21, 2006; accepted for publication August 10, 2006; published online August 21, 2006

Communicating editor: K.J. Flynn

In this study, we compare the composition, abundance and structure of a temperate fish larval assemblage at different depth intervals $(0-4,4-8$ and $8-12 \mathrm{~m})$ in the extreme nearshore environment. We used a plankton net attached to an underwater scooter to sample in close proximity to the rocky substrate $(<50 \mathrm{~cm})$. A total of 868 larvae from 27 taxa in 13 families were caught. The majority of larvae belonged to benthic reef-associated species (Blennïdae, Gobïdae, Gobiesocidae and Tripterygïdae), the four most abundant comprising $76 \%$ of the total larvae caught. A non-metric multidimensional scaling analysis (MDS) showed that there was a single multispecific larval patch near the substrate in the extreme nearshore up to $12 \mathrm{~m}$ depth. Nonetheless, distinct larval abundances were found in this relatively small depth range, with the majority of species being more abundant at the deepest interval, particularly Pomatoschistus pictus and Gobius xanthocephalus. Tripterygion delaisi was an exception being more abundant at the shallowest depth as young larvae. The density of pre-flexion larvae was not significantly different across depth intervals, but post-flexion larval density increased with depth. The full size range (from hatching to settlement) of $P$. pictus was present at the extreme nearshore. The innovative sampling technique used here revealed high densities of larvae close to the bottom, and depth was found to be an important factor influencing the distribution of several taxa and ontogenetic stages. The nearshore component of coastal fish larval assemblages near rocky substrates has been poorly studied, and our results suggest that the high densities of larvae found to aggregate in these environments must be taken into account when studying distribution and functional aspects of these assemblages.

\section{INTRODUGTION}

The spatial distribution of larvae (both horizontal, from the coast to open water environments, and vertical, from the surface to the sea bottom) can be a major determinant of adult population sizes (Sinclair, 1988). However, in temperate coastal areas, studies on larval distribution have focused mainly on commercial fishes and at offshore waters (Neilson and Perry, 1990; Cushing, 1995), whereas coastal rocky bottom species have received little attention (Leis and McCormick, 2002).

Horizontal distributional studies have found that inshore larval assemblages have a distinct composition from that of offshore assemblages (Marliave, 1986; Sabatés, 1990; Gray, 1993) and are also characterized by higher densities of shorefishes (Sabatés, 1990; Gray, 1993; Jenkins et al., 1999; Sabatés et al., 2003). Horizontal distribution can however be strongly influenced by the vertical position of larvae in the water column (Armsworth, 2001). In coastal waters (<100 m deep), vertical distribution patterns have been described for several taxa (Leis, 1991a; Cowen, 2002). In some of the few vertical distribution studies performed in inshore waters, higher abundances of larvae were found in the deeper water layer (Gray, 1993), and there is growing 
evidence of vertical depth-related distribution of larvae even at small spatial scales (Leis, 1991a, 1991b). Taxonspecific vertical distribution patterns were described by several authors at small spatial scales, mainly in coral reefs (Leis, 1991b; Hendricks et al., 2001) but also in temperate waters (Boehlert et al., 1985). A highly structured vertical distribution pattern of nearshore coral reef fish larvae with several taxa (e.g. Labridae and Gobiidae) being more abundant in deeper waters during the day has been described (Leis, 1991b). Hendricks et al. (Hendricks et al., 2001) also found some gobies to be more abundant at deeper water.

Ontogenetic vertical distribution of larvae in coastal waters is also poorly understood. Little evidence of agerelated vertical distribution was found for several taxa on coral reefs (Leis, 1991b). On the contrary, Cowen (Cowen, 2002) found pre-flexion larvae to occur shallower than post-flexion larvae to be the most common pattern, as is the case of the damselfish Stegastes partitus (Paris and Cowen, 2004).

Most of these studies have assessed the vertical distribution of larvae in the water column and have traditionally relied on methods such as oblique tows (Boehlert et al., 1985; Leis, 1991b; Paris and Cowen, 2004), vertical hauls (Gray, 1996), horizontal tows (Olivar and Sabatés, 1997; Sabatés et al., 2003) and hand net collections (Marliave, 1986). These methods are however inadequate to sample over high-relief bottoms at the extreme nearshore as they miss those specimens that stay close to the bottom (Leis, 1991b; Olivar and Sabatés, 1997). Even though the development of light traps allowed sampling in these environments (Milicich et al., 1992; Hendricks et al., 2001), this method attracts only photopositive larvae from varying distances and possibly from all directions, making a clear indication of the exact position of the larvae caught impossible. Therefore, there is a sampling gap in ichthyoplankton studies of nearshore assemblages because the water layer close to the bottom is not sampled most of the times. Late-stage larvae, in particular, are known to school at close proximity to the bottom in coastal areas (Leis, 1986; Breitburg, 1989, 1991; Steffe, 1990) where they can profit from particular current regimes (Marliave, 1986) that ultimately enable them to remain nearshore.

Even though there is evidence for the presence of some larval stages near the bottom at the nearshore, the epibenthic water layer remains to be adequately sampled, and the effect of depth over the distribution of larvae near the bottom is not known. In this study, we propose to fill this sampling gap in nearshore larval distribution studies using a diver-steered sampling method. The following questions are addressed: How do larval assemblage composition, abundance and structure change with depth close to the bottom? Are there taxon-specific vertical distribution patterns? Are there differences between ontogenetic stages in their vertical distribution?

\section{METHOD}

\section{Sampling location and period}

This study was carried out at the Arrábida Marine Park (west coast of Portugal $-38^{\circ} 27^{\prime} 03^{\prime \prime} \mathrm{N}, 009^{\circ} 01^{\prime} 24^{\prime \prime} \mathrm{W}$ ) in July 2002, during the spawning season of most of the resident species (E. J. Gonçalves et al., unpublished data). The extreme nearshores were selected for sampling in the sector of the Park with the highest biodiversity (Gonçalves et al., 2003). Underwater rocky habitats extend to $\sim 13 \mathrm{~m}$ depth and are highly heterogeneous resulting from the disintegration of the calcareous cliffs that border the coastline. This area faces south and is therefore highly protected from the prevailing north and northwest winds and waves.

\section{Sampling methodology}

A plankton net (mouth diameter $30 \mathrm{~cm}$; mesh size $350 \mu \mathrm{m}$; diameter/length ratio 1:3) attached to an Apollo AV-1 underwater scooter was used to sample in close proximity to the substrate (closer than $50 \mathrm{~cm}$ ) (Fig. 1). A Hydrobios flowmeter attached to the mouth opening measured the volume of filtered water (mean volume $=8.51 \mathrm{~m}^{-3} \mathrm{SD}=$ $\left.2.70 \mathrm{~m}^{-3}\right)$. Trawling speed was $\sim 1.3$ knots $(\mathrm{SD}=0.21$, $\mathcal{N}=10$ ). In spite of the low speed, advanced stage larvae of several species were caught. Therefore, net avoidance by larvae due to low trawling speed does not seem to be a problem in this study.

Sampling was performed in the morning in good sea and weather conditions. Each sample consisted of a 5-min trawl parallel to the shoreline. After reaching the bottom, the diver opened the net and began the trawl following a direction parallel to the shoreline. Three depth intervals were chosen: $0-4,4-8$ and 8-12 $\mathrm{m}$. These depth intervals

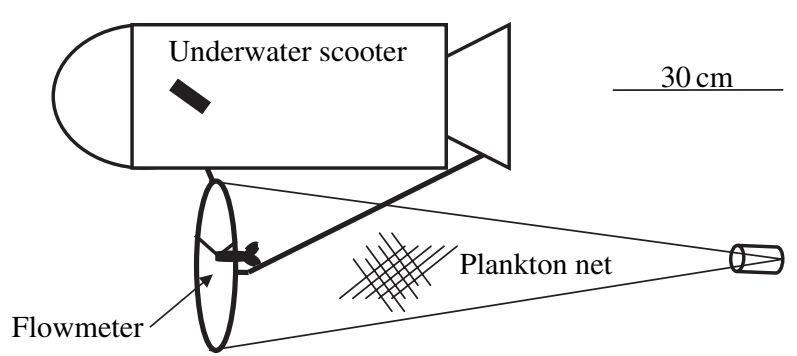

Fig. 1. Diagram of the scooter-plankton net apparatus used for sampling. 
were chosen according to the ability to accompany the bottom relief in an approximately straight line, avoiding large obstacles when necessary, without leaving the chosen depth strata with the aid of a diving computer attached to the scooter. A total of 27 samples were taken at each depth, 3 days a week collecting three samples a day for 3 weeks, totalizing 81 samples. The trawls were performed around the middle depth value in each depth interval selected. For each sample, the difference between the maximum and minimum sampling depths was on average $2.22 \mathrm{~m}(\mathrm{SD}=0.54)$.

Larvae were preserved in $4 \%$ buffered formalin for at least 1 month and identified to the lowest taxonomic level possible $(6.8 \%$ of the larvae could not be identified). Larvae were assigned a developmental stage according to the flexion stage of the urostyle, following Leis and Carson-Ewart (Leis and Carson-Ewart, 2000) but considering only two categories: 'pre-flexion' and 'post-flexion' (after initiation of the flexion process). Larval length is defined as body length (BL) and corresponds to notochord length in pre-flexion larvae or to the standard length (SL) in post-flexion larvae. Measurements were taken to the nearest $0.1 \mathrm{~mm}$ using a micrometer scale under a stereomicroscope $3.3 \%$ of the larvae were damaged and therefore were not measured).

\section{Statistical analysis}

Two diversity indexes were calculated for each sample. The Shannon diversity index $\left(H^{\prime}\right)$ was calculated from the proportional abundances $p_{i}$ of each species (abundance of the species/total abundances, noted here as $p_{i}=$ $\left.n_{i} / \mathcal{N}\right)$ using the natural logarithm in its formulation. This index reflects diversity based on the number of species and relative abundance of each species (Zar, 1996).

$$
H^{\prime}=\sum_{i=1}^{s} p_{i} \ln \left(p_{i}\right)
$$

The average taxonomic distinctness index $\left(\Delta^{*}\right)$ where $\mathrm{X}_{i}(i=1, \ldots, s)$ denotes the abundance of the $i$ th species, $n\left(=\Sigma_{j} X_{i}\right)$ is the total number of individuals in the sample and $\omega_{i j}$ is the 'distinctness weight' given to the path length linking species $i$ and $j$ in the hierarchical classification. The double summations are overall pairs of species $i$ and $j$ (with $i<j$ ). For the calculation of $\Delta^{*}$, equal step-lengths were assumed between these taxonomic levels: family, genera and species. This index reflects the taxonomic spread of species among samples (Clarke and Warwick, 1999).

$$
\Delta^{*}=\left[\sum \sum_{i<j} \omega_{i j} X_{i} X_{j}\right] /\left[\sum \sum_{i<j} X_{i} X_{j}\right]
$$

Differences in these indexes across depths were tested using a one-way ANOVA for the $H^{\prime}$ and a KruskalWallis ANOVA for the $\Delta^{*}$ given that normality assumptions were not met in the second case (Zar, 1996).

Differences in total densities and densities of pre-flexion and post-flexion larvae per sample among depths were tested using the Kruskal-Wallis test given that data did not conform to normality or homogeneity of variances. The post hoc Dunn's test was used to identify where differences lay (Zar, 1996).

The assemblage structure analysis was performed with the multivariate statistical package Primer-E (Clarke and Warwick, 2001). A Bray-Curtis similarity index for $\log (x+$ 1) transformed data was applied to the sample matrix (abundance of each species per sample) to decrease the contribution from numerically dominant species. A nonmetric multidimensional scaling (MDS) was applied to the similarity matrix to visualize the relationships among samples. In this plot, samples that are closer together are less distinct, and the stress coefficient measures the extent to which the plot displays the relationships among samples (Clarke and Warwick, 2001). The analysis of similarities test (ANOSIM) was used to investigate differences in the structure of the assemblage between depth intervals (999 permutations). This test is analogous to a univariate analysis of variance and identifies whether differences between the MDS groupings are significant.

Differences in size (BL) at each depth interval were compared among all the specimens of the four most abundant species. Given that data did not conform to normality and variances were not homogeneous even after transformation, Kruskal-Wallis ANOVAs and post hoc Dunn's tests or a Mann-Whitney $U$ test, were used to identify differences between the sizes of larvae across depths.

\section{RESULTS}

\section{Assemblage composition}

The 868 larvae captured belonged to 27 taxa in 13 families (Table I). The majority of larvae (74\%) belonged to benthic reef-associated species of the families Gobiidae, Blenniidae, Tripterygiidae and Gobiesocidae, with $52 \%$ of the species common to all depth intervals. The four most abundant ones (Pomatoschistus pictus, Gobius xanthocephalus, Tripterygion delaisi and Symphodus melops) comprised $76 \%$ of the total larvae caught. Several species occurred in the deeper interval but were absent or very scarce in the shallowest interval: Lepadogaster sp., Lepadogaster candolii, Ctenolabrus rupestris and Symphodus bailloni, Sparidae spl and Sparidae spp. Some species 


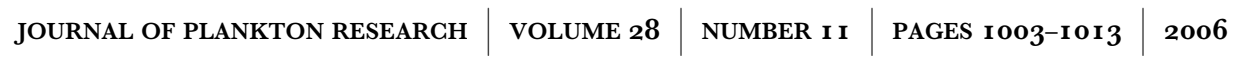

Table I: Mean density $\pm S D$ for each species in each depth interval given in specimens $/ 1000 \mathrm{~m}^{-3}$

\begin{tabular}{|c|c|c|c|c|c|}
\hline \multirow[t]{2}{*}{ Family } & \multirow[t]{2}{*}{ Genus } & \multirow[t]{2}{*}{ Species } & \multicolumn{3}{|l|}{ Mean \pm SD } \\
\hline & & & $0-4 \mathrm{~m}$ & $4-8 \mathrm{~m}$ & $8-12 m$ \\
\hline \multirow[t]{2}{*}{ Blenniidae } & Parablennius & Parablennius pilicornis & $12.06 \pm 42.66$ & $4.68 \pm 24.33$ & $6.49 \pm 33.74$ \\
\hline & Coryphoblennius & Coryphoblennius galerita & $3.50 \pm 16.81$ & 0 & 0 \\
\hline Bothidae & Arnoglossus & Arnoglossus thori & $4.72 \pm 22.66$ & $30.88 \pm 137.36$ & $8.09 \pm 42.02$ \\
\hline Callionymidae & Callionymus & Callionymus spp. & $10.90 \pm 28.94$ & $33.13 \pm 78.23$ & $24.50 \pm 76.24$ \\
\hline Carangidae & Trachurus & Trachurus trachurus & $8.20 \pm 27.17$ & $5.53 \pm 28.72$ & 0 \\
\hline Clupeidae & Sardina & Sardina pilchardus & $15.51 \pm 34.64$ & $71.41 \pm 194.08$ & $67.88 \pm 144.57$ \\
\hline Engraulidae & Engraulis & Engraulis enchrasicolus & 0 & $8.73 \pm 45.38$ & 0 \\
\hline \multirow[t]{2}{*}{ Gobiesocidae } & Lepadogaster & Lepadogaster candolii & 0 & 0 & $16.78 \pm 69.98$ \\
\hline & Lepadogaster & Lepadogaster lepadogaster & 0 & 0 & $4.73 \pm 24.59$ \\
\hline \multirow[t]{5}{*}{ Gobiidae } & No id & Gobiidae spp. & $22.16 \pm 38.40$ & $13.06 \pm 67.85$ & $8.09 \pm 42.02$ \\
\hline & Gobius & Gobius xanthocephalus & $71.03 \pm 224.14$ & $72.39 \pm 120.27$ & $415.92 \pm 777.74$ \\
\hline & Gobiusculus & Gobiusculus flavescens & $2.96 \pm 14.21$ & $7.78 \pm 28.12$ & 0 \\
\hline & Pomatoschistus & Pomatoschistus microps & 0 & 0 & $8.36 \pm 43.42$ \\
\hline & Pomatoschistus & Pomatoschistus pictus & $97.26 \pm 163.67$ & $412.85 \pm 512.68$ & $1808.64 \pm 2397.32$ \\
\hline \multirow[t]{7}{*}{ Labridae } & Centrolabrus & Centrolabrus exoletus & $3.60 \pm 17.25$ & 0 & $72.65 \pm 143.31$ \\
\hline & Coris & Coris julis & 0 & $13.78 \pm 51.53$ & 0 \\
\hline & Ctenolabrus & Ctenolabrus rupestris & 0 & $4.17 \pm 21.66$ & $28.01 \pm 78.38$ \\
\hline & Symphodus & Symphodus bailloni & 0 & $31.66 \pm 76.54$ & $17.26 \pm 50.00$ \\
\hline & Symphodus & Symphodus melops & $4.13 \pm 19.82$ & $118.35 \pm 185.49$ & $93.57 \pm 131.27$ \\
\hline & Symphodus & Symphodus spp. & $4.10 \pm 19.67$ & $34.95 \pm 88.23$ & $67.42 \pm 97.75$ \\
\hline & Symphodus & Symphodus roissali & $19.29 \pm 37.65$ & $34.73 \pm 101.05$ & $6.49 \pm 33.74$ \\
\hline No id & No id & No id & $20.72 \pm 48.74$ & $26.64 \pm 59.79$ & $42.00 \pm 90.53$ \\
\hline Serranidae & Serranus & Serranus spp. & $9.10 \pm 30.56$ & $21.08 \pm 62.75$ & 0 \\
\hline Soleidae & No id & Soleidae spp. & $4.10 \pm 19.67$ & $14.38 \pm 59.57$ & $8.09 \pm 42.02$ \\
\hline \multirow[t]{3}{*}{ Sparidae } & Boops & Boops boops & $4.10 \pm 19.67$ & $31.73 \pm 80.34$ & $111.72 \pm 188.45$ \\
\hline & No id & Sparidae sp1 & 0 & $5.03 \pm 26.14$ & $62.96 \pm 162.92$ \\
\hline & No id & Sparidae spp. & 0 & $5.53 \pm 28.72$ & $53.71 \pm 173.03$ \\
\hline \multirow[t]{2}{*}{ Tripterygiidae } & Tripterygion & Tripterygion delaisi & $110.33 \pm 130.39$ & $67.92 \pm 99.28$ & $50.87 \pm 103.95$ \\
\hline & & Total & $427.78 \pm 956.71$ & $1070.39 \pm 2178.11$ & $2990.69 \pm 4980.71$ \\
\hline
\end{tabular}

No id, unidentified larvae.

presented an inverse pattern, as they were captured at the shallowest interval, in low densities, and were absent from the deeper interval: Coryphoblennius galerita, Trachurus trachurus, Gobiusculus flavescens and Serranus spp. In terms of total diversity, both the Shannon diversity index and the average taxonomic distinctness index were not significantly different across depths (Table II).

\section{Species abundances}

There were significant differences across depths in total larval densities KKruskal-Wallis test: $H(2, n=81)=$ 38.14; $P<0.001]$. All depth intervals were significantly different from each other, with higher densities registered at the deepest interval (Fig. 2). In each depth interval, the abundance rank for the different species changed. In the shallowest interval, the most abundant species was T. delaisi, followed by $P$. pictus and $G$. xanthocephalus. In the 4- to 8-m interval, $P$. pictus dominated followed by $S$. melops and $G$. xanthocephalus. Finally, in the deeper interval, $P$. pictus was again the dominant species followed by $G$. xanthocephalus and Boops boops (Table I). Overall, $P$. pictus was the most abundant species. At the species level, the only significant differences in densities across depth strata were recorded for $P$. pictus $[H(2, n=81)=33.161 ; P<0.001]$ and $G$. xanthocephalus $[H(2, n=81)=7.599 ; P<0.05]$. The highest differences were registered between extreme depth intervals for $P$. pictus (Dunn's test: $0-4$ and $4-8 \mathrm{~m}, P<0.05$; 0-4 and $8-12 \mathrm{~m}, P<0.001 ; 4-8$ and $8-12 \mathrm{~m}, P<0.01)$ and G. xanthocephalus (Dunn's test: $0-4$ and $4-8 \mathrm{~m}$, n.s.; 0-4 and $8-12 \mathrm{~m}, P<0.05 ; 4-8$ and $8-12 \mathrm{~m}$, n.s.). 
Table II: Shannon diversity index $\left(H^{\prime}\right)$ and average taxonomic distinctness index ( $\left.\Delta *\right)$ in each depth interval

\begin{tabular}{llllllrr}
\hline Depth $(\mathrm{m})$ & $n$ & Average $H^{\prime}$ & SD $H^{\prime}$ & Test & $P$ & Average $\Delta^{*}$ & SD $\Delta^{*}$ \\
\hline $0-4$ & 27 & 0.84 & 0.54 & & 77.67 & 38.97 \\
$4-8$ & 27 & 0.95 & 0.55 & $H=4.26$ & 0.127 & 74.67 & 33.49 \\
$8-12$ & 27 & 1.07 & 0.39 & & 91.29 & 0.284 \\
\hline
\end{tabular}

$F$, value of one-way ANOVA; $H$, value of Kruskal-Wallis test.

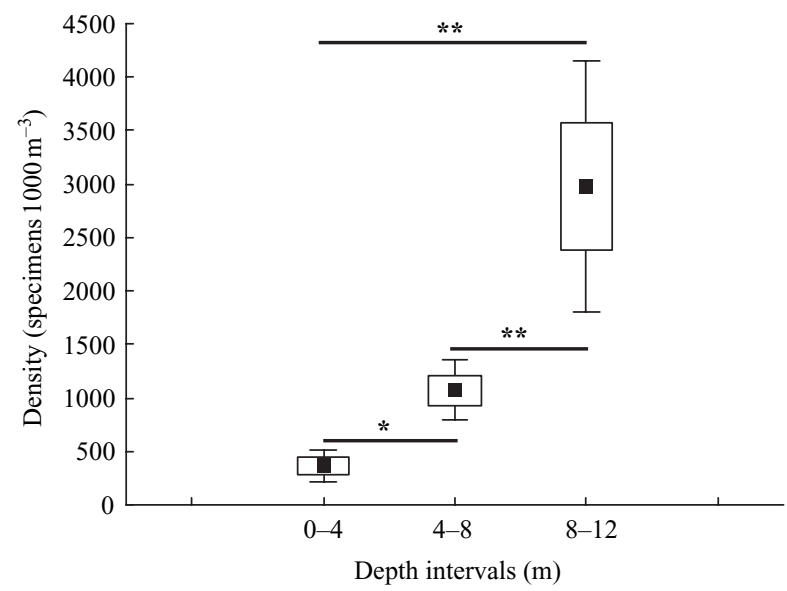

Fig. 2. Larval density variation across depth intervals. Mean density (black square), mean $\pm \mathrm{SE}$ (boxes) and mean $\pm 1.96 \times \mathrm{SE}$ (whiskers). Post hoc test results represented by $* P<0.01$ and $* * P<0.001$.

\section{Assemblage structure}

The MDS did not show a clear segregation across depth intervals (Fig. 3). The stress coefficient obtained was 0.16 which is inferior to the value of 0.2 considered the limit to adequately represent similarity or dissimilarity between samples in the MDS plot (Clarke and

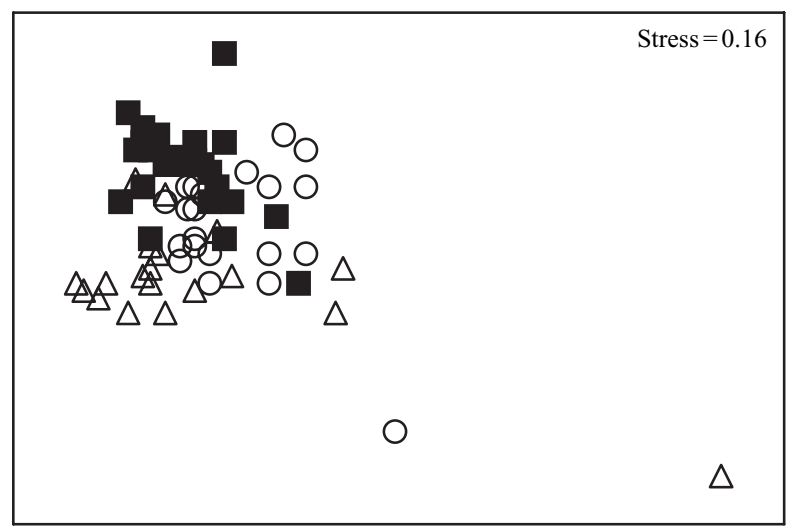

Fig. 3. Non-metric multidimensional scaling (MDS) based on the similarity matrix of samples by species. $0-4 \mathrm{~m}=\Delta ; 4-8 \mathrm{~m}=\bigcirc ; 8-12$ $\mathrm{m}=$
Warwick, 2001). The ANOSIM analysis revealed significant differences between depths, but the global $R$ value was low (global $R=0.16, P=0.001$ ). This means that the differences in assemblage structure observed across depth intervals were not very strong (Clarke and Warwick, 2001). Pair-wise comparisons between depth intervals yielded low $R$ values $(0-4$ versus $4-8 \mathrm{~m}: R=0.12, P=$ $0.007 ; 4-8$ versus $8-12 \mathrm{~m}: R=0.053, P=0.015 ; 0-4$ versus $8-12 \mathrm{~m}: R=0.341, P=0.001)$. The small difference in structure observed between the extreme depth intervals is likely the result of two factors: (i) the smaller number of taxa shared between the extreme depth intervals $(n=14)$ than between any other pair of depth intervals $(0-4$ versus $4-8 \mathrm{~m}, n=17 ; 4-8$ versus $8-12 \mathrm{~m}$, $n=18$ ) as well as (ii) the great difference in average densities of the most abundant species between extreme depths (e.g. P. pictus varied two orders of magnitude and $G$. xanthocephalus varied one order of magnitude).

\section{Ontogenetic vertical distribution}

There were no significant differences in the density of preflexion larvae across depths $[H(2, \mathcal{N}=81)=1.74, P=0.42]$ (Fig. 4A). On the contrary, post-flexion larvae were significantly more abundant at the two deepest intervals $[H(2$, $\mathcal{N}=81)=34.30, P<0.001$; post hoc tests only found differences between $0-4$ and $4-8 \mathrm{~m}, P<0.01$ and $0-4$ and 8-12 m, $P<0.001]$ (Fig. 4B). The size of the four most abundant species changed with depth. All size classes of $P$. pictus larvae, from hatching to recruitment and varying between 1.6 and $18 \mathrm{~mm} \mathrm{BL}$, were present near the bottom, (Fig. 5). In the deepest interval, mean larval sizes were significantly smaller than in the intermediate depth, but larvae caught at the shallowest depth were not significantly different from others $[H(2, \mathcal{N}=429)=68.28, P<0.001$; post hoc tests only found differences between $4-8$ and $8-12 \mathrm{~m}$, $P<0.001]$. Nevertheless, $P$. pictus larvae were present in the whole size range at all depths. Gobius xanthocephalus larvae ranged between 5.5 and $14 \mathrm{~mm}$ BL (Fig. 6). Significant differences in size were found across depth intervals $[H(2$, $\mathcal{N}=117)=49.37, P<0.001]$, with larvae caught at $8-12 \mathrm{~m}$ being significantly smaller than at both $0-4 \mathrm{~m}(P<0.001)$ and $4-8 \mathrm{~m}(P<0.001)$. In fact, the pre-flexion larvae of 

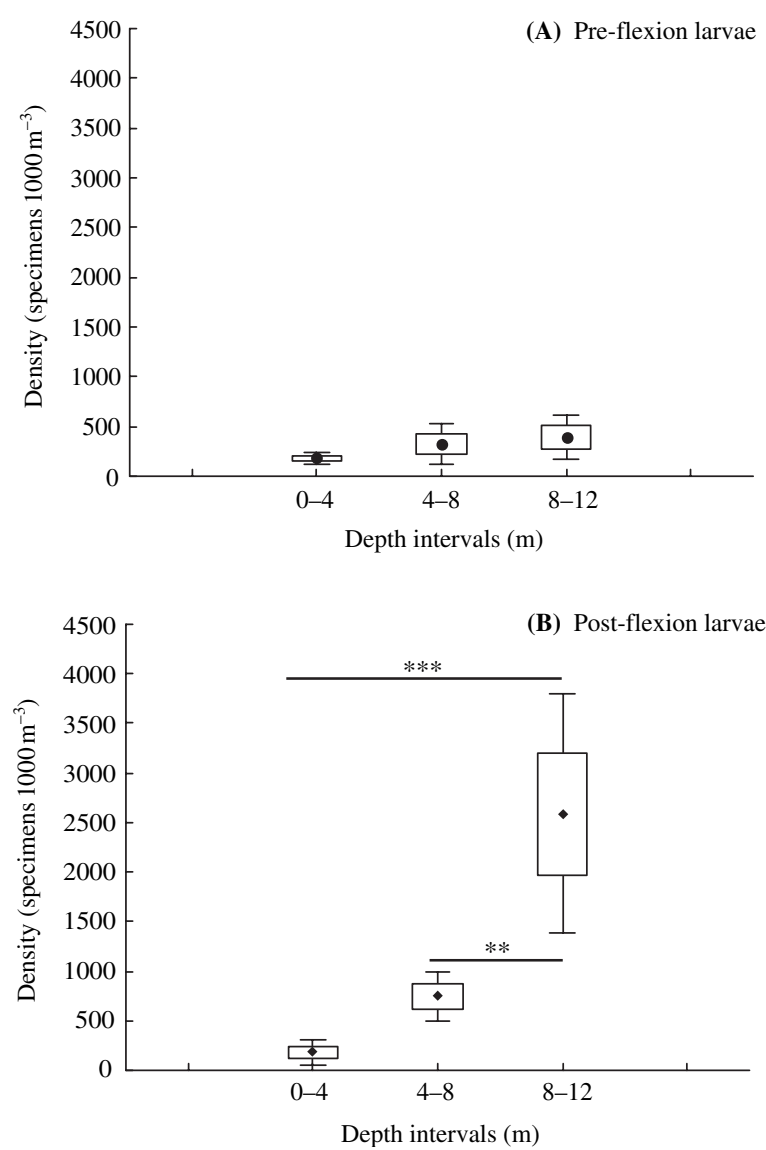

Fig. 4. Larval density variation across depth intervals for $(\mathbf{A})$ preflexion and $(\mathbf{B})$ post-flexion larvae. Mean density of $(\mathbf{A})$ pre-flexion (black circle) and (B) post-flexion larvae (black diamond), mean \pm SE (boxes) and mean $\pm 1.96 \times \mathrm{SE}$ (whiskers). Post hoc test results represented by $* P<0.01$ and $* * P<0.001$.

G. xanthocephalus were not collected in any depth interval. Tripterygion delaisi larvae captured were between 3 and $6 \mathrm{~mm}$ BL (Fig. 7) and were more abundant in the shallowest depth interval (Table I). There were, however, no significant differences between the sizes of these larvae across the whole depth range $[H(2, \mathcal{N}=49)=2.11, P=0.348]$. Symphodus melops larvae ranged from 5.5 to $8.4 \mathrm{~mm} \mathrm{BL} \mathrm{(Fig.} \mathrm{8)} \mathrm{and}$ were significantly larger at the deepest interval [MannWhitney $U$ test; $\mathcal{N}(4-8 \mathrm{~m})=22$ and $\mathcal{N}(8-12 \mathrm{~m})=17$; $Z=-2.22, P<0.05]$. However, pre-flexion individuals were not captured at any depth interval. The only specimen of $S$. melops captured at the shallowest depth was $6.9 \mathrm{~mm}$ SL and was not considered in this analysis.

\section{DISGUSSION}

In this study, larvae were sampled across depths using an innovative method that enables a fine resolution of vertical distributions near the bottom. To our knowledge,
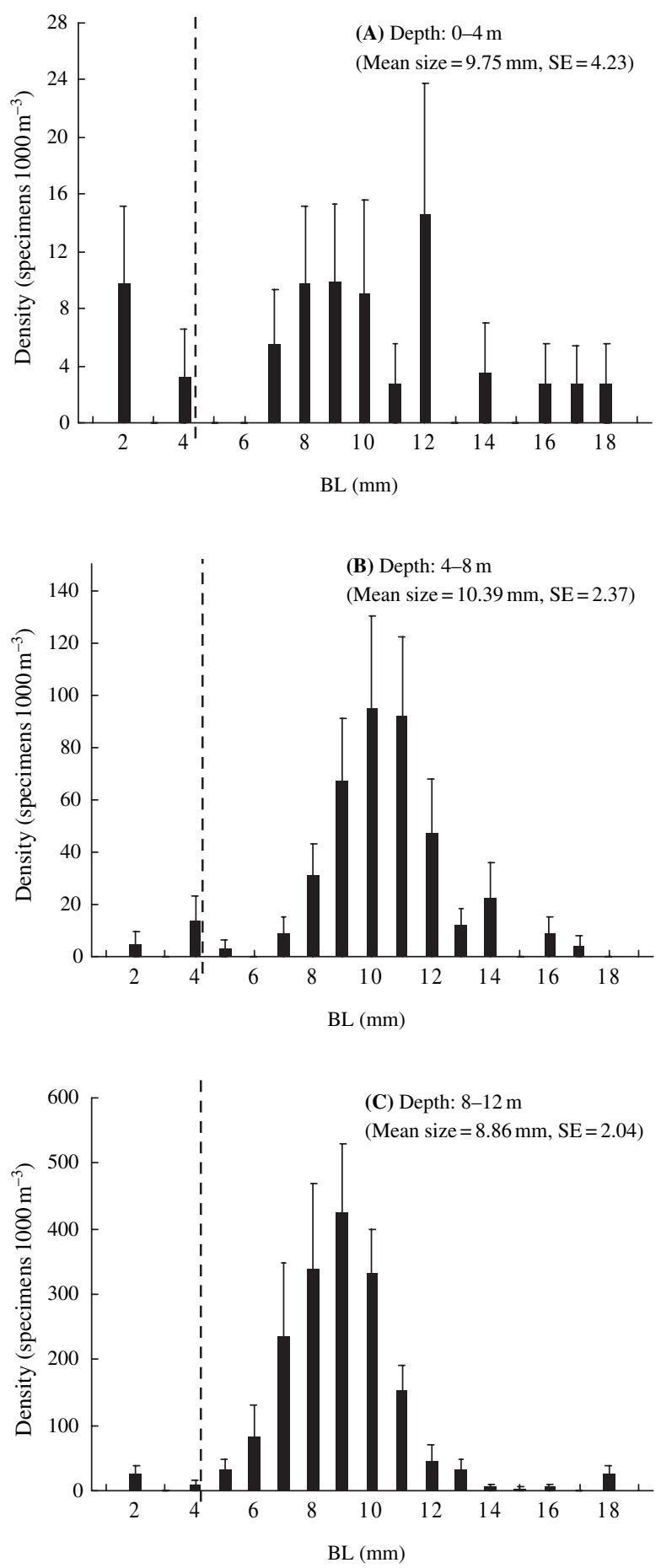

Fig. 5. Body length (BL) range of Pomatoschistus pictus in each depth interval (A) 0-4 m, (B) 4-8 $\mathrm{m}$ and $(\mathbf{C})$ 8-12 $\mathrm{m}$ presented as the mean density (columns) and SE (whiskers). Mean BL and SE are presented between brackets. Vertical dashed lines separate the pre-flexion larvae from post-flexion larvae.

the use of a plankton net attached to an underwater scooter to sample nearshore ichthyoplankton assemblages has only been used by Goldman et al. (1983) on 

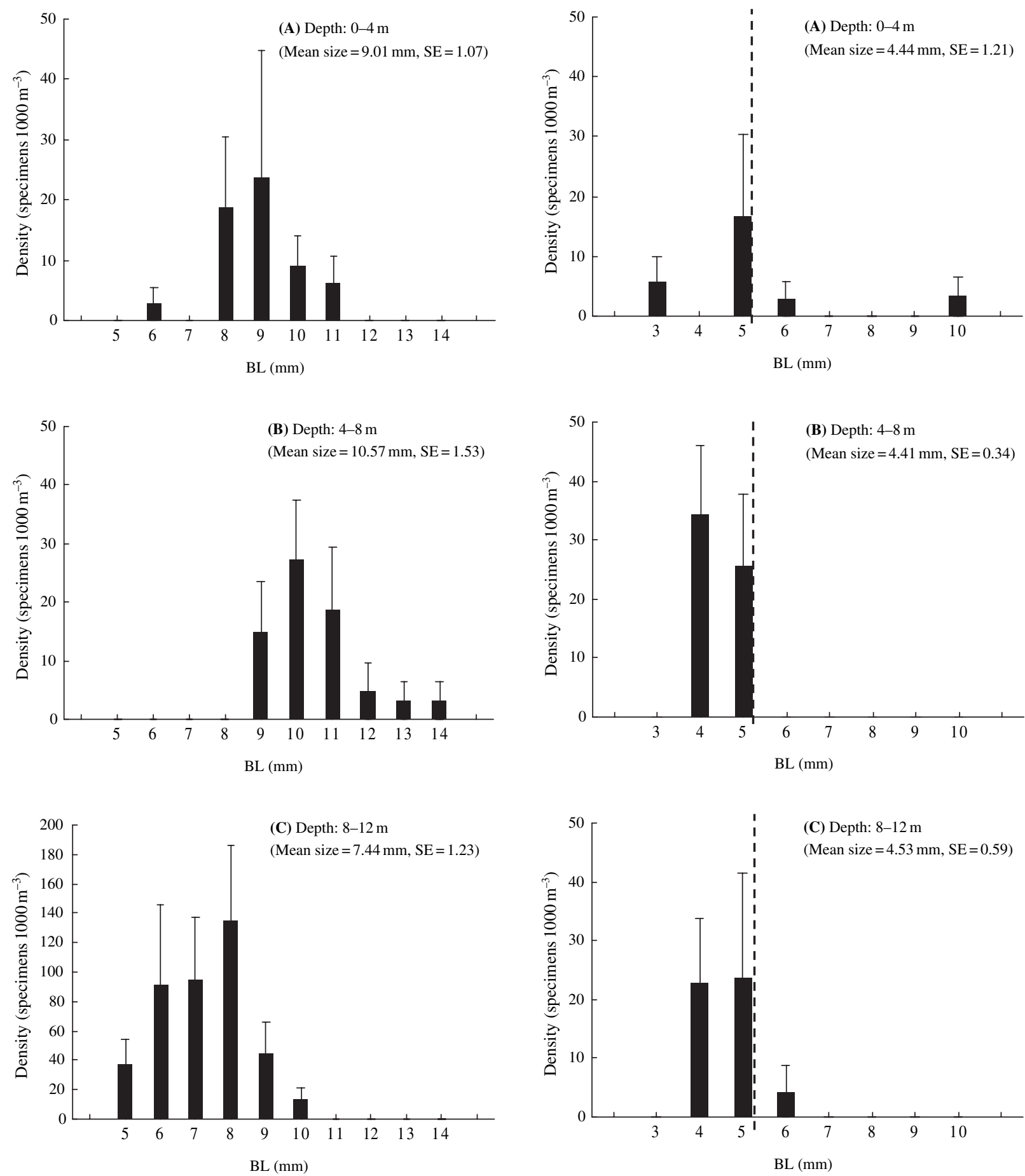

Fig. 6. Body length (BL) range of Gobius xanthocephalus in each depth interval (A) 0-4 m, (B) 4-8 m and (C) 8-12 $\mathrm{m}$ presented as the mean density (columns) and SE (whiskers). Mean BL and SE are presented between brackets.

various coral reef habitats at Lizard Island (Great Barrier Reef, Australia), but no larvae were identified by these authors, and therefore, an evaluation of the observed

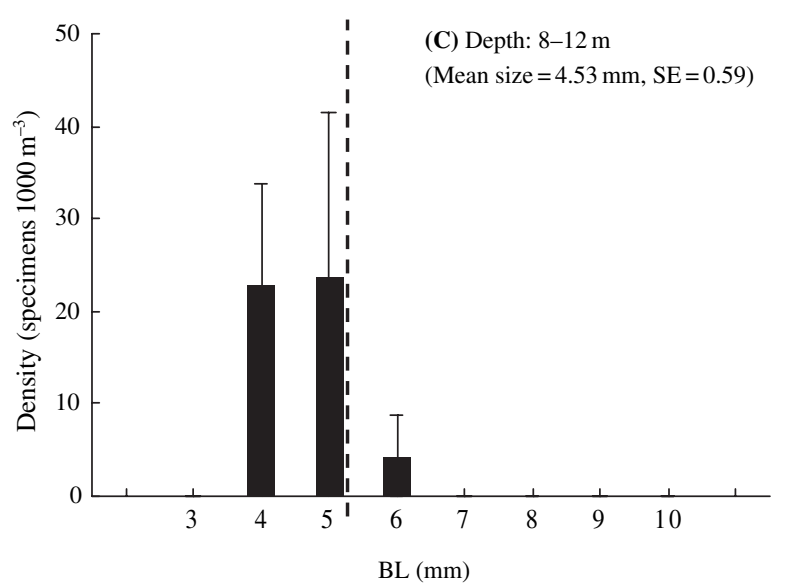

Fig. 7. Body length (BL) range of Tripterygion delaisi in each depth interval (A) 0-4 m, (B) 4-8 $\mathrm{m}$ and $(\mathbf{C}){ }^{8}$-12 $\mathrm{m}$ presented as the mean density (columns) and SE (whiskers). Mean BL and SE are presented between brackets. Vertical dashed lines separate the pre-flexion larvae from post-flexion larvae.

trends is not possible (see also Leis, 1991a). Distinct depth strata were characterized and compared in terms of taxonomic composition and diversity, total density, 

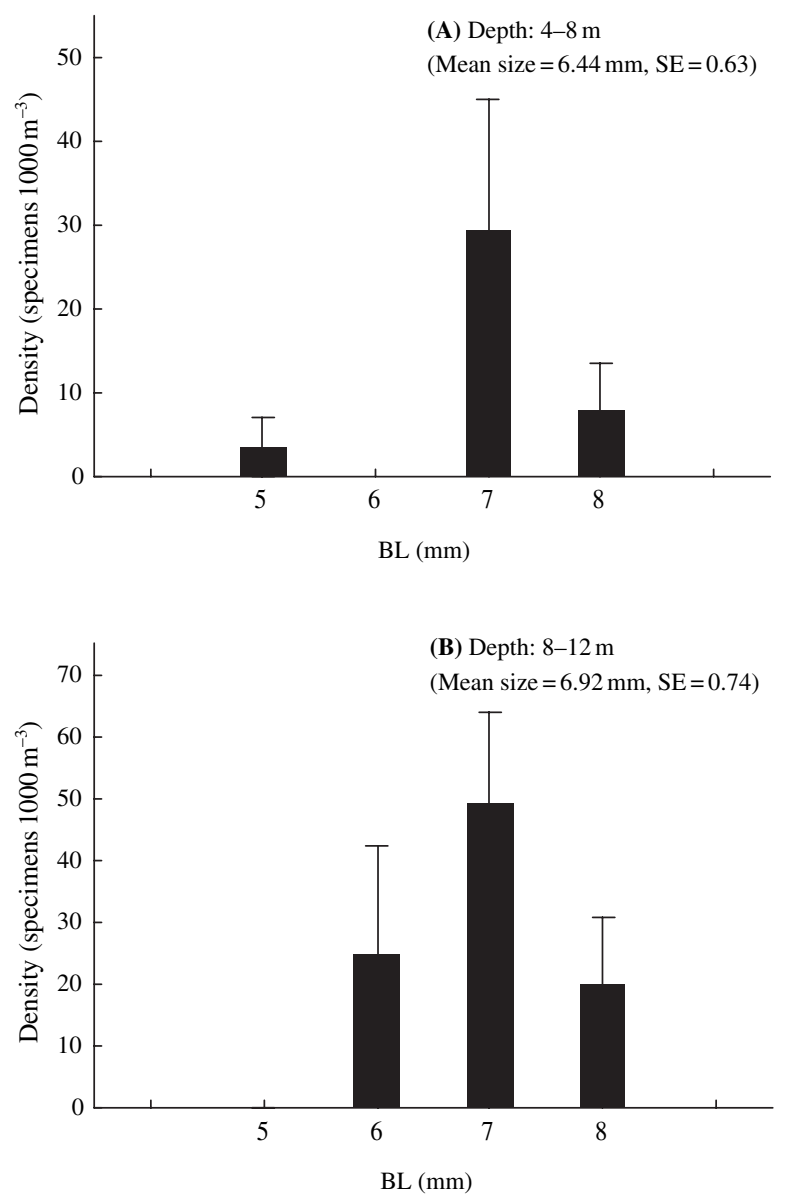

Fig. 8. Body length (BL) range of Symphodus melops in each depth interval (A) $0-4 \mathrm{~m}$ and $(\mathbf{B}) \quad 4-8 \mathrm{~m}$ presented as the mean density (columns) and SE (whiskers). Mean BL and SE are presented between brackets.

assemblage structure and ontogenetic composition. Clear differences were found across depths for taxonomic, ontogenetic composition and total larval density but not in diversity or assemblage structure.

The very nearshore larval assemblage described here was mainly composed of shore fishes. Occurrence of larvae from the families Gobiidae, Labridae and Tripterygiidae has also been described in other nearshore studies performed both in temperate (Gray, 1993; Gray and Miskiewicz, 2000; Sabatés et al., 2003) and in tropical regions (Leis, 1986, 1991a; Thorrold and Williams, 1996). In this study, P. pictus larvae represented $>50 \%$ of all larvae caught. Larvae from other springsummer spawners, which are very abundant in the study area as adults, in particular Lepadogaster sp. and Parablennius pilicornis (Henriques et al., 1999; Gonçalves et al., 2003), were almost absent from our nearshore captures. The few specimens caught were invariably locally produced newly hatched larvae. These species may be present at other depths in the water column; they may disperse offshore or somehow avoid capture by the method we used. Lepadogaster sp. and newly hatched $P$. pilicornis larvae have been captured in high abundances at night at the same site (R. Borges et al., unpublished data). Older stages of $P$. pilicornis have not been captured close to shore; these larvae may disperse offshore such as described by Olivar (1986) in other regions.

Even though there were several species unique to one or two depth intervals, there were no significant differences for any of the diversity indexes calculated across depth intervals. In the few studies that have analysed larval diversity at different depth strata nearshore, Sponaugle et al. (Sponaugle et al., 2003) found no differences in diversity at different depths, while Leis (Leis, 1986) found higher diversity in deeper water. In the former study, sampling was performed at $1-5 \mathrm{~m}$ depth over an $8 \mathrm{~m}$ deep bottom and in the latter sampling was performed at $0-6 \mathrm{~m}$ over $10-15 \mathrm{~m}$ bottoms. In both these studies, however, the water layer near the bottom was not sampled; hence, the effect of depth on diversity in this layer was not ascertained. The present study showed that for the depth range sampled, depth had no effect on diversity close to the bottom and that assemblage structure did not change with depth. Therefore, in our study area, a single larval patch seems to exist close to the bottom in the extreme nearshore. However, there was a slight difference between the extreme depth strata, which is probably related to the lower number of common taxa between these strata and also to the higher densities of the most abundant species ( $P$. pictus), which were 18 times higher in the deepest interval.

In spite of the above-described results regarding diversity and structure, overall larval densities close to the bottom were significantly different among relatively narrow depth intervals. Higher densities were registered in the deepest interval, whereas lower densities were recorded for the shallowest interval. Higher larval abundances in deeper waters were also found by Leis (Leis, 1986) and Gray (Gray, 1993), although the near bottom layer was not sampled in those studies. The present study showed that depth may influence smallscale larval distributions with taxon-specific patterns in close proximity to the bottom. Whereas P. pictus and G. xanthocephalus were significantly more abundant in the deepest interval, T. delaisi was more abundant at the shallowest interval and S. melops at the intermediate depth strata. Some of the reasons why larvae were more abundant at particular depth intervals may be related to water movement, specific behaviours or the interaction of these factors. The small and microscale 
water circulation at the study area is not known; however, this is a factor that can strongly influence the distribution of larvae (Marliave, 1986; Leis, 1991a; Reiss et al., 2000; Paris and Cowen, 2004). Also, different species can respond to different sensorial cues (Myrberg and Fuiman, 2002), and strong swimming abilities have been described for some shore fish larvae (Fisher, 2005), allowing them to control their position in the water column. Furthermore, Breitburg et al. (Breitburg et al., 1995) suggested that larvae may respond to particular current regimes associated to bottom topography. A better understanding of the larval behaviour of the different species and the microscale patterns of oceanographic features at the study site might help explain the differences observed across depths.

Another interesting result of this study is the variation across depths of the overall pattern of distribution between developmental stages. We found significantly higher densities of post-flexion larvae at the two deepest strata but found no differences for the pre-flexion larvae. The increase of post-flexion larvae with depth has also been described for several species (Cowen, 2002; Paris and Cowen, 2004). However, those studies did not sample the epibenthic water layer.

We found that post-flexion larvae also occur near the bottom even at shallow depths. Proximity to the substrate is an important factor influencing the distribution of larvae; therefore, the epibenthic water layer should be sampled in vertical distribution studies. Moreover, depth is also an important factor influencing the distribution of post-flexion larvae near the bottom at the very nearshore given that there was a clear increase in the number of post-flexion larvae in the deeper intervals. At the species level, T. delaisi presented no distinct ontogenetic vertical distribution pattern. For $S$. melops, larvae were larger at greater depths. On the contrary, G. xanthocephalus larvae were smaller at the greatest depth with the smallest larvae (5-8 $\mathrm{mm} \mathrm{BL}$ ) being present only at the deepest interval. Intermediate size larvae $(8-10 \mathrm{~mm} \mathrm{BL})$ of this species were present at all depths, and the largest larvae were found only at the intermediate depth interval.

The hatching and settlement sizes are not known for G. xanthocephalus larvae; nonetheless, specimens ranging from 5 to $14 \mathrm{~mm}$ BL were captured. In the case of $P$. pictus, larvae were present in the full range of sizes (and development stages) at all depth strata from hatching, which is $2.8 \mathrm{~mm}$ (Lebour, 1920), to settlement, which is 17-18 mm (Petersen, 1919), but were smaller at the deeper strata than at the intermediate depth. These data indicate that $P$. pictus and
G. xanthocephalus may be spending their entire pelagic phase in close proximity to the reefs. Other studies have also shown that the whole range of larval developmental stages in gobies may occur near shore. In the Dutch delta, the full range of larval sizes of Pomatoschistus spp. (both P. minutus and P. lozanoi) was present near the substrate (Beyst et al., 1999). In the French Polynesia, several taxa, including Gobiidae, were present in different lagoons in the full larval size range (Leis et al., 2003). This is also the case of other species found in inshore waters such as Oligocottus maculosus (Marliave, 1986) and Callionymus simplicicornis (Leis et al., 1998). Thus, the presence of larval stages near shore may be a common phenomenon among certain coastal fish species. Remaining close to shore may have several advantages among which are finding a suitable settlement habitat at the end of the larval stage (Hickford and Schiel, 2003) and growing in a more productive environment.

Small-scale studies of larval fish distribution, like the present one, provide important evidence on the distribution and abundance of fish larvae at nearshore waters and could greatly benefit from the integration with behavioural studies and characterization of the oceanographic features of each study site. One central aspect for the interpretation of the patterns found in this and other studies, which remains to be fully acknowledged, is the role of larval behaviour and its interaction with small-scale physical features of the nearshore environments at different geographic areas and oceanographic conditions. This is probably a fruitful direction for future studies of nearshore fish larval distributions.

\section{AGKNOWLEDGEMENTS}

This study was supported by the Portuguese Science and Technology Foundation (Fundação para a Ciência e a Tecnologia-FCT) as part of the project POCTI/BSE/38350/2001 and through the Pluriannual Program (R\&D Unit 331/94). FCT also supported the $\mathrm{PhD}$ grants of R. Beldade (SFRH/BD/ 1013/2000) and R. Borges (SFRH/BD/4852/2001). We thank Dr Alexandra Chícharo and Dr Radhouan Ben-Hamadou for their help in the statistical analysis, M. Barbosa, A. Catarino, J. Martins, N. Souza and S. Vizinho for assistance in the field and lab work and the Oceanographic Museum of Parque Natural da Arrábida for support. We also thank two anonymous referees whose comments helped us improve the initial manuscript. 


\section{REFERENGES}

Armsworth, P. R. (2001) Directed motion in the sea: efficient swimming by reef fish larvae. f. Theor. Biol., 210, 81-91.

Beyst, B., Mees, J. and Cattrijsse, A. (1999) Early postlarval fish in the hyperbenthos of the Dutch Delta (south-west Netherlands). F. Mar. Biol. Assoc. U.K., 79, 709-724.

Boehlert, G. W., Gadomski, D. M. and Mundy, B. C. (1985) Vertical distribution of ichthyoplankton off the Oregon coast in spring and summer months. Fish. Bull. U.S., 83, 611-621.

Breitburg, D. L. (1989) Demersal schooling prior to settlement by larvae of the naked goby. Environ. Biol. Fish., 26, 97-103.

Breitburg, D. L. (1991) Settlement patterns and presettlement behavior of the naked goby, Gobiosoma bosci., a temperate oyster reef fish. Mar. Biol., 109, 213-221.

Breitburg, D. L., Palmer, M. A. and Loher, T. (1995) Larval distributions and the spatial patterns of settlement of an oyster reef fish: responses to flow and structure. Mar. Ecol. Prog. Ser., 125, 45-60.

Clarke, K. R. and Warwick, R. M. (1999) The taxonomic distinctness measure of biodiversity: weighting on step lengths between hierarchical levels. Mar. Ecol. Prog. Ser., 184, 21-29.

Clarke, K. R. and Warwick, R. M. (2001) Change in Marine Communities: an Approach to Statistical Analysis and Interpretation, 2nd edn. PRIMER-E, Plymouth, 172 pp.

Cowen, R. K. (2002) Larval dispersal and retention and consequences for population connectivity. In Sale, P. F. (ed.). Coral Reef Fishes: Dynamics and Diversity in a Complex Ecosystem. Academic Press, San Diego, pp. 149-170.

Cushing, D. (1995) Population Production and Regulation in the Sea - a Fisheries Perspective. Cambridge University Press, Cambridge.

Fisher, R. (2005) Swimming speeds of larval coral reef fishes: impacts on self-recruitment and dispersal. Mar. Ecol. Prog. Ser., 285, 223-232.

Goldman, B., Stroud, G. J. and Talbot, F. (1983) Fish eggs and larvae over a coral reef: abundance with habitat, time of day and moon phase. In Baker, J. T., Carter, R. M., Sammarco, P. W. and Stark, K. P. (eds). Proceedings: Inaugural Great Barrier Reef Conference. James Cook University Press, Townsville, Australia, pp. 203-211.

Gonçalves, E. J., Henriques, M. and Almada, V. C. (2003) Use of a temperate reef-fish community to identify priorities in the establishment of a Marine Protected Area. In Beumer, J. P., Grant, A. and Smith, D. C. (eds). Aquatic Protected Areas: What Works Best and How Do We Know? Proceedings of the World Congress on Aquatic Protected Areas, Cairns, Australia. Australian Society for Fish Biology, North Beach, Western Australia, Australia, pp. 261-272.

Gray, C. A. (1993) Horizontal and vertical trends in the distributions of larval fishes in coastal waters off central New South Wales, Australia. Mar. Biol., 116, 649-666.

Gray, C. A. (1996) Small-scale temporal variability in assemblages of larval fishes: implications for sampling. F. Plankton Res., 18, $1643-1657$.

Gray, C. A. and Miskiewicz, A. G. (2000) Larval fish assemblages in south-east australian coastal waters: seasonal and spatial structure. Est. Coastal Shelf Sci., 50, 549-570.

Hendricks, I. E., Wilson, D. T. and Meekan, M. G. (2001) Vertical distributions of late stage larval fishes in the nearshore waters of the San Blas Archipelago, Caribbean Panama. Coral Reefs, 20, 77-84.
Henriques, M., Gonçalves, E. J. and Almada, V. G. (1999) The conservation of littoral fish communities. A Case Study at Arrábida Coast (Portugal). In Almada, V. C., Oliveira, R. F. and Gonçalves, E. J. (eds). Behaviour and Conservation of Littoral Fishes. ISPA, Lisboa, pp. 473-519.

Hickford, M. J. H. and Schiel, D. R. (2003) Comparative dispersal of larvae from demersal versus pelagic spawning fishes. Mar. Ecol. Prog. Ser., 252, 255-271.

Jenkins, G. P., Black, K. P. and Keough, M. J. (1999) The role of passive transport and influence of vertical migration on the presettlement distribution of a temperate demersal fish: numerical model predictions compared with field sampling. Mar. Ecol. Prog. Ser., 184, 259-271.

Lebour, M. V. (1920) The eggs of Gobius minutus, pictus and microps. F. Mar. Biol. Assoc. U.K., 12, 253-260.

Leis, J. M. (1986) Vertical and horizontal distribution of fish larvae near coral reefs at Lizard Island, Great Barrier Reef. Mar. Biol., 90, $505-516$.

Leis, J. M. (1991a) The pelagic stage of reef fishes: the larval biology of coral reef fishes. In Sale, P. F. (ed.). The Ecology of Fishes on Coral Reefs. Academic Press, San Diego, pp. 183-230.

Leis, J. M. (1991b) Vertical distribution of fish larvae in the Great Barrier Reef Lagoon, Australia. Mar. Biol., 109, 157-166.

Leis, J. M. and Carson-Ewart, B. M. (2000) The larvae of Indo-Pacific coastal fishes. An Identification Guide to Marine Fish Larvae. Brill, Leiden.

Leis, J. M. and McCormick, M. I. (2002) The biology, behavior, and ecology of the pelagic, larval stage of coral reef fishes. In Sale, P. F. (ed.). Coral Reef Fishes: Dynamics and Diversity in a Complex Ecosystem. Academic Press, San Diego, pp. 171-199.

Leis, J. M., Trnski, T., Doherty, P. J. and Dufour, V. (1998) Replenishment of fish populations in the enclosed lagoon of Taitoro Atoll (Tuamotu Archipelago, French Polynesia) evidence from eggs and larvae. Coral Reefs, 17, 1-8.

Leis, J. M., Trnski, T., Dufour, V., Harmelin-Vivien, M., Renon, J.-P. and Galzin, R. (2003) Local completion of the pelagic larval stage of coastal fishes in coral-reef lagoons of the Society and Tuamoto Islands. Coral Reefs, 22, 271-290.

Marliave, J. B. (1986) Lack of planktonic dispersal of rocky intertidal fish larvae. Trans. Am. Fish. Soc., 115, 149-154.

Milicich, M. J., Meekan, M. G. and Doherty, P. J. (1992) Larval supply: a good predictor of recruitment of three species of reef fish (Pomacentridae). Mar. Ecol. Prog. Ser., 86, 153-166.

Myrberg, A. A. Jr and Fuiman, L. A. (2002) The sensory world of coral reef fishes. In Sale, P. F. (ed.). Coral Reef Fishes: Dynamics and Diversity in a Complex Ecosystem. Academic Press, San Diego, pp. 123-148.

Neilson, J. D. and Perry, R. I. (1990) Diel vertical migrations of marine fishes: an obligate or facultative process? Adv. Mar. Biol., 26, 115-168.

Olivar, M. P. (1986) Development and distribution of Parablennius pilicornis (Cuvier) larvae (Teleostei: Blenniidae) off Namibia. S. Afr. 7. Mar. Sci., 4, 193-201.

Olivar, M. P. and Sabatés, A. (1997) Vertical distribution of fish larvae in the north-west Mediterranean Sea in spring. Mar. Biol., 129, 289-300.

Paris, C. B. and Cowen, R. K. (2004) Direct evidence of a biophysical retention mechanism for coral reef fish larvae. Limnol. Oceanogr., 49 , 1964-1979.

Petersen, G. G. J. (1919) Our Gobies (Gobiidae). From the egg to the adult stages. Report Dan. Biol. Stn., 26, 45-66. 
Reiss, C. S., Panteleev, G., Taggart, C. T., Sheng, J. and deYoung, B. (2000) Observations on larval fish transport and retention on the Scotian Shelf in relation to geostrophic circulation. Fish. Oceanogr., 9, 195-213.

Sabatés, A. (1990) Distribution pattern of larval fish populations in the Northwestern Mediterranean. Mar. Ecol. Prog. Ser., 59, 75-82.

Sabatés, A., Zabala, M. and Gárcia-Rubies, A. (2003) Larval fish communities in the Medes Islands Marine Reserve (North-West Mediterranean). f. Plankton Res., 25, 1035-1046.

Sinclair, M. (1988) Marine Populations: an Essay on Population Regulation and Speciation. Washington Sea Grant Program. University of Washington Press, Seattle, 252 pp.
Sponaugle, S., Fortuna, J., Grorud, K. and Lee, T. (2003) Dynamics of larval fish assemblages over shallow coral reef in the Florida Keys. Mar. Biol., 143, 175-189.

Steffe, A. S. (1990) Epibenthic schooling by larvae of the Atherinid fish Leptatherina presbyteroides: an effective mechanism for position maintenance. Jpn. F. Ichthyol., 36, 488-491.

Thorrold, S. R. and Williams, D. M. (1996) Meso-scale distribution patterns of larval and pelagic juvenile fishes in the central Great Barrier Reef lagoon. Mar. Ecol. Prog. Ser., 145, 17-31.

Zar, J. H. (1996) Biostatistical Analysis, 3rd edn. Prentice Hall, Upper Saddle River, NJ. 